Історико-політичні проблеми сучасного світу: Збірник наукових статей. - Чернівці: Чернівецький національний університет, 2020. - T. 42. - C. 204-213

DOI: $10.31861 / \mathrm{mhpi} 2020.42 .204-213$
Modern Historical and Political Issues: Journal in Historical \& Political Sciences. - Chernivtsi: Chernivtsi National University, 2020. - Volume. 42. - pp. 204-213 DOI: $10.31861 / \mathrm{mhpi} 2020.42 .204-213$

\title{
327.82(438:477)"2013/2020"
}

(C) Віталій Моцок ${ }^{1}$

\section{Задля поширення демократії чи подолання кризи: політичний й ідеологічний вплив Польщі на Україну в умовах Української кризи}

У статті досліджується політичний й ідеологічний вплив Польщі на Україну в умовах Української кризи, наголошуючи на питанні чи зусилля Польщі були спрямовані на поширення демократії, здебільшого з боку Європейського Союзу, чи на подолання кризи в Україні. Стаття складається з двох частин: у першій частині досліджується польський політичний й ідеологічний вплив на Україну під час розвитку Української кризи в 2013-2014 рр., яка відбувалася в умовах Євромайдану і Революції Гідності і в контексті зусиль СС із поширення демократії щодо України. Друга частина спрямована на вивчення сприяння Польщі у боротьбі із поширенням російського авторитаризму в умовах російсько-української гібридної війни 2014-2020 рр. Українську кризу і посткризовий процес ми розглядаємо як значний мотивуючий фактор, який здійснює важливу роль у посиленні демократичних орієнтацій українського суспільства, а участь зовнішніх сил, передусім консолідованого Заходу, як його істотний чинник. Українська криза 2013-2020 pр. $є$ цікавим кейсом для визначення можливостей головних донорів із зовнішнього поширення демократії для цільових країн, в нашому випадку, України.

Ключові слова: поширення демократії, політичний й ідеологічний вплив, Польща, Українська криза.

\section{Promoting Democracy or Overcoming the Crisis: Poland's Political and Ideological Influence on Ukraine in its Crisis}

The article deals with Poland's political and ideological influence towards Ukraine in the conditions of its crisis, emphasizing the question whether these efforts have been made due to reasons of democracy promotion, mainly of European origin, or Ukraine crisis overcoming. The article consists of two parts: 1) Polish political and ideological influence on Ukraine during the development of Ukraine crisis 2013-2014, which took place in the conditions of the Euromaidan and the Revolution of Dignity and in the context of the EU democracy promotion endeavors towards Ukraine; 2) Poland's efforts to prevent spreading of Russia's authoritarianism in the context of hybrid war between Russia and Ukraine during 2014-2020. The Ukrainian crisis is closely linked to the spread of democracy, the EU integration and Russian ideological influence. Terminologically, we support the research position in the interpretation of the Ukrainian crisis as a socio-political unrest, which began in late November 2013. The main hypothesis implies that the external democracy promotion could be more effective in the case of domestic crisis in the recipient country. Therefore, the Ukrainian crisis of 2013-2020 is an interesting case to determine the capabilities of the main donors for the external democracy promotion for the target countries, in our case, Ukraine. Poland took an active part both in promoting democracy towards Ukraine and in overcoming Ukraine crisis, using its own political and ideological resources. We consider the Ukrainian crisis and the post-crisis process as an important motivating factor that plays an important role to strengthen the democratic aspirations of Ukrainian society. Moreover, the participation of external forces, especially of the consolidated West is a significant factor in this process.

Keywords: democracy promotion, political and ideological influence, Poland, Ukraine crisis.

\footnotetext{
1 Кандидат політичних наук, доцент кафедри міжнародних відносин Чернівецького національного університету імені Юрія Федьковича, Україна. E-mail: vmotsok@yahoo.com; htts:/orcid.org/ 0000-00023963-4807.
} 
Постановка наукової проблеми та їі значення. Практична реалізація концепції поширення демократії підтверджує свою високу ефективність у просуванні цінностей, які фундаментально змінюють суспільства і формують нові умови для ще кардинальніших змін того чи іншого політичного режиму у глобальному вимірі і на перспективу. Українська держава пройшла декілька етапів демократизації, починаючи з часу розпаду СРСР, отримуючи поштовхи і ресурси як з внутрішніх джерел, так і зовнішніх. Свропейський Союз, використовуючи обумовленість членства, ефективно маніпулював, змінюючи політичні режими у своїй околиці, які демонстрували прагнення вступити в СС. У результаті цього, країни пострадянського і постсоціалістичного табору, що приєдналися до $С$ в 2004 р. і 2007 р., зазнали кардинальних трансформацій, завдячуючи, передусім, механізмам поширення демократії.

Найбільш новітнім прикладом національного прагнення із демократичного оновлення політичного режиму, поруч із активними зовнішніми імпульсами, стали широкі народні протести в Республіці Білорусь у контексті президентських виборів 9 серпня 2020 р. і поствиборчий період, які увійшли у політологічний дискурс як Білоруська революція ${ }^{2}$ Беручи до уваги активну роль зовнішніх сил у ході розвитку масового протестного руху і посилення демократичних аспірацій білоруського народу, ми припускаємо, що практична реалізація зовнішнього поширення демократії не втратила своєї актуальності, вагомості й ефективності на цьому етапі на пострадянському просторі. Ми вважаємо, що імпліцитні ресурси масового електорального протесту володіють потенціалом до серйозного зростання на фоні посилення жорсткості з боку навіть консолідованих демократій на глобальному рівні у контексті боротьби із новим коронавірусом.

Ми трактуємо поширення демократії як глобальний і скоординований процес трансформації недемократичних політичних режимів у результаті дії факторів внутрішнього і зовнішнього походження. У свою чергу, зовнішне поширення демократії ми трактуємо як цілеспрямовану, організовану і ефективну політику головних держав-донорів щодо впливу на політичні режими, які не демонструють ознак демократичної консолідації або показують прояви дегенерації демократичного режиму. Конструювання більш безпечної і прогнозованої системи міжнародних відносин у майбутньому є головною метою поширення демократії. Завдячуючи механізмам зовнішнього поширення демократії, як обумовленість вступу в ЄС і НАТО, більшість політичних режимів зі Східної Європи відповідають європейським критеріям щодо трактування консолідованих політичних режимів станом на кінець 2020 p.

3-поміж основних цільових країн-реципієнтів щодо яких застосовувалися механізми зовнішнього поширення демократії, Україна посідає вагоме місце, оскільки саме в ній вже відбулися дві електоральні революції й одна з перших у світовій практиці гібридна війна, як війна нового типу, яка пов'язана 3-поміж іншого й з боротьбою на ідеологічному рівні. Це демонструє унікальне значення України у регіональній політиці, наповнює іï порядок денний і формує перспективи розвитку всього східноєвропейського простору. У свою чергу, Польща, від часу свого вступу в ЄС в 2004 р., сприяла Європейському Союзу у формуванні спільної політики на східноєвропейському напрямку, зокрема й щодо поширення демократії. Крім цього, Польща може похизуватися своїм суверенним баченням перспектив східноєвропейського простору в умовах розвитку тих чи інших викликів ${ }^{3}$.

Симптоматично, що Українська криза тісно пов'язана із поширенням демократії, інтеграцією в СС і російським ідеологічним впливом. Термінологічно, ми підтримуємо дослідницьку позицію в трактуванні Української кризи як соціально-політичного загострення, яке розпочалося у кінці листопада 2013 р., а саме із не підписання Вільнюської декларації, і наступним Євромайданом/Революцію Гідності ${ }^{4}$. На жаль, зважаючи на відсутність позитивної динаміки із врегулювання конфлікту гібридного типу на сході України і в Криму, слід трактувати Українську кризу й у теперішньому часі, або на час написання цієї статті. Трагічні події, пов’язані із Укра-

\footnotetext{
2 Дивіться, наприклад: Sierakowski, S. (2020), Belarus Uprising: The Making of a Revolution, Journal of Democracy, Vol. 31, № 4, pp. 5-16.

3 Дивіться, наприклад: Zajaç, J. (2016), Poland's Security Policy The West, Russia, and the Changing International Order. Palgrave Macmillan.

${ }^{4}$ Дивіться, наприклад: Krasnodebska, M. (2020), Managing the Ukraine Crisis: A Triumph of Poland's EU Politics? Politics of Stigmatization. Poland as a 'Latecomer' in the European Union. Palgrave Studies in International Relations, p. 187-225.
} 
їнською кризою 2013-2020 рр., позначилися на розвитку українсько-польських відносин, оскільки обидвом державам довелося зіткнутися із новими викликами у своїй внутрішній і зовнішній політиці. Україна прагнула підтримки з боку традиційних союзників, 3-поміж яких $є$ й Польська держава, натомість Польща намагалася зберегти традиційне бачення своєї східної політики, незважаючи на доволі терпиму політику ЄС щодо Російської Федерації.

Аналіз останніх досліджень та публікацій. У нашій роботі ми скористалися доробком дослідників, котрі вивчають прояви політичного й ідеологічного впливу Польщі на Україну в контексті Української кризи. 3-поміж науковців, які досліджують аспекти поширення демократії і подолання Української кризи у контексті зовнішньополітичної присутності ЄС і Російської Федерації, ми скористалися працями М. Краснодембської 5 , О. Бурлюк ${ }^{6}$ Р. Зіємби П. Пошпієшної й А. Галус ${ }^{9}$ Й. Заячковського ${ }^{10}$, Я. Кухарчика і А. Фуксієвіча ${ }^{11}$, Л. Ликошиної ${ }^{12}$, А. Бієнчик-Міссали ${ }^{13}$, А. Шептицького ${ }^{14}$, А. Турковського ${ }^{15}$ 3-поміж багатьох інших ${ }^{16}$.

Метою статті є визначити цілі і ступінь політичного й ідеологічного впливу Польщі на Україну в контексті Української кризи і посткризового розвитку, визначаючи поширення демократії і подолання кризи як дві ймовірні, однак не протилежні цілі.

Завданнями статті є: визначити політико-ідеологічний вплив Польщі на Україну під час розвитку Української кризи 2013-2014 pp. і показати сприяння Польщі Україні у боротьбі із поширенням російського авторитаризму.

Представлена стаття сформована 3 двох частин, які корелюються із завданнями: перша частина стосується політико-ідеологічного впливу Польщі на Україну під час розвитку Української кризи 2013-2014 рр. в умовах політики СС із просування демократії; друга спрямована на вивчення сприяння Польщі у боротьбі із поширенням російського авторитаризму в умовах російсько-української гібридної війни 2014-2020 рр.

Гіпотеза полягає у тому, що зовнішне поширення демократії може бути ефективнішим в умовах внутрішньополітичної кризи у країні-реципієнті. Тому, Українська криза і посткризовий період 2013-2020 рр. $є$ цікавим кейсом для визначення можливостей головних донорів із зовнішнього поширення демократії для цільових країн, в нашому випадку, України. Отже, ми припускаємо, що поширення демократії, як більш тривалий і фундаментальний процес, потребує залучення різного роду мотивуючих тригерів, які можуть зіграти епізодичну, однак, вагому,

\footnotetext{
${ }^{5}$ Krasnodeb̨ska, M., (2020), op.cit.; Krasnodębska, M. (2014), Europeanization of Poland's Strategic Culture: Managing the 2013/14 Ukraine Crisis Paper Proposal. Available at: https://ecpr.eu/Filestore/paperproposal/ 48346673-2aa6-4313-9eb1-1e05bb00d5ec.pdf [Viewed 1 December 2020].

${ }^{6}$ Burlyuk, O. (2017), Same End, Different Means: The Evolution of Poland's Support for Ukraine at the European Level, East European Politics and Societies and Cultures, Vol. 31, № 2, p. 311-333.

${ }^{7}$ Zięba, R. (2020), Poland's Foreign and Security Policy Problems of Compatibility with the Changing International Order. Palgrave Macmillan.

${ }^{8}$ Zajaç, J. (2016), Poland's Security Policy The West, Russia, and the Changing International Order. Palgrave Macmillan.

${ }^{9}$ Pospieszna, P. \& Galus, A. (2018), Promoting active youth: evidence from Polish NGO's civic education programme in Eastern Europe, Journal of International Relations and Development, Vol. 23, № 1, p. 210-236.

${ }^{10}$ Zajaczkowski, J. (2017), Trading Solidarity For Security? Poland And The Russian-Ukrainian Crisis, Идеология и политика, №1(17), p. 168-234.

${ }^{11}$ Kucharczyk, J \& Fuksiewicz, A (2015), The Long Shadow of the Kremlin: Polish Domestic Reactions to the Russian-Ukrainian Conflict, Kucharczyk, J \& Mesežnikov, G (eds), Diverging Voices, Converging Policies: The Visegrad States' Reactions to the Russia-Ukraine Conflict, Heinrich-Böll-Foundation, p. 102-114.

12 Лыкошина, Л. (2015), Российско-польские отношения в 2004-2014 гг.: От Майдана до Майдана, Страны Восточной Европы и Россия: развитие отношений в 2005-2015 гг.: сб. науч. тр. Отв. ред. Игрицкий И.Ю. ИНИОН РАН, Москва, с. 29-46.

${ }^{13}$ Bienczyk-Missala, A. (2016), Poland's Foreign And Security Policy: Main Directions, Revista UNISCI / UNISCI Journal, № 40, p. 101-118.

${ }^{14}$ Szeptycki, A. (2016), Poland-Ukraine Relations, Revista UNISCI / UNISCI Journal, №40 (Enero / January), p. 57-76.

${ }^{15}$ Turkowski, A (2018), Polish Intelligentsia Totems in Elites' Struggles for Legitimization: The Case of Jerzy Giedroyc and Poland's Eastern Policy, East European Politics and Societies and Cultures, Vol. 33, № 1, p. 6688.

${ }^{16}$ Формат цієї статті нам не дозволяє згадати всіх дослідників, які працюють у сфері поширення демократії і подолання Української кризи у зовнішній політиці СС і Польщі щодо України.
} 
роль на тому чи іншому етапі. Таким чином, Українську кризу і посткризовий процес ми розглядаємо як значний мотивуючий фактор, який здійснює важливу роль у посиленні демократичних орієнтацій українського суспільства, а участь зовнішніх сил, передусім консолідованого Заходу, як його істотний чинник.

Виклад основного матеріалу дослідження. У даній статті ми зосереджуємося на можливостях зовнішнього поширення демократії в умовах Української кризи, головними компонентами якої стали Євромайдан/Революція Гідності 2013-2014 pр., постреволюційний розвиток і українсько-російська гібридна війна 2014-2020 рр. Для нас так само важливим є вищезазначений третій компонент, а саме ідеологічна складова протистояння між Заходом і Російською Федерацією у вигляді гібридної війни, яка на практиці донедавна реалізовувалося лише в Україні ${ }^{17}$. Подолання цього конфлікту є запорукою для активізації європейських прагнень України, які не можуть бути реалізованим без демократичної обумовленості країни-кандидата на вступ в ЄС. Російська Федерація таким чином пригальмувала процес європейської інтеграції України, однак чи пригальмувала вона процес демократизації України?!

Демократизація України упродовж 1991-2020 рр. значно відрізнялася від тих процесів, що мали місце в Центральній Європі, передусім, через обмежене використання важелів європейської інтеграції, однак, на противагу більшості політичних режимів з Центральної Свропи, в Україні були використані інші механізми, які теж довели свою високу ефективність у процесі внутрішньополітичних перетворень, проте вони були набагато більш радикальними $\mathrm{i}$ не прив'язаними до кінцевої мети вступу в СС. Свропейський Союз, як головний зовнішній гравець, теж долучився до просування демократії в Україні, щоправда іншими інструментами, які не передбачали вступ України в СС на передбачувану перспективу. В цілому, зовнішнє поширення демократії зводилося до посилення впливу тих чи інших країн чи міжнародних організацій на країну-реципієнта, задля прискорення змін в її внутрішній політиці, що врешті й сталося в результаті Української кризи 2013-2014рр. і посткризового період. Туманність чи навіть відсутність перспективи членства в ЄС для України робить справу ії демократизації не зовсім зрозумілою $з$ точки зору впливів таких зовнішніх гравців як Європейський Союз, США чи Польща.

Соціально-політична і військова криза в Україні, починаючи з кінця 2013 р., виявилася ризикованим майданчиком для поширення тих чи інших цінностей, оскільки від результатів протистояння залежав напрямок розвитку іiі ідеологічного фундаменту. Свромайдан і Революція Гідності відкрили можливості для зовнішнього поширення демократії, зокрема й з боку Польщі. Цілі політичного й ідеологічного впливу Польщі на Україну під час Української кризи слід, передусім, розглядати у контексті зовнішньополітичної присутності Європейського Союзу у цій частині світу. У свою чергу, Польща, як долучилася до політики поширення демократії Європейського Союзу щодо східноєвропейського простору, i, зокрема, України, починаючи з часу свого вступу в СС, так і приєдналася до подолання Української кризи з самого ії̈ початку.

У цій частині поставлено за мету визначити ступінь ефективності посередництва Польщі у політиці поширення демократії Європейським Союзом щодо України упродовж періоду активного формування дискурсу поширення демократії, що відбувався у контексті Української кризи (2013-2020). 3 часу вступу в ЄС, Польща приєдналася до формування і реалізації порядку денного Європейського Союзу із поширення демократії щодо України, хоча головним актором у поширенні демократії щодо України і Східної Європи виступав власне ЄС. Польща приєдналася до цього процесу, використовуючи переваги власного регіонального лідерства, зм'якшуючи недоліки $Є С$ і посилюючи необхідні політичні процеси в Україні, які, у свою чергу, повинні були призвести до більш радикальних трансформацій у цій частині європейського континенту i формувати проекцію на весь пострадянський простір. Погодимося з О. Бурлюк, що Українська криза може показати чи «дійсно Польща просунулася в політичній ієрархії $Є С$ », та виміряти

\footnotetext{
${ }^{17}$ Масові виступи населення в Білорусі або Білоруська революція, яка відбулася наприкінці літа-восени 2020 р. у контексті виборчого циклу, показала, що ідеологічна боротьба за східноєвропейський простір наростає й iï об’єктом стає ще одна держава пострадянського простору, яка тривалий час демонструвала консерватизм і латентність у необхідності трансформації власного політичного режиму. Це може свідчити про формування нового циклу нестабільності у Східній Європі після формального зниження напруженості у регіоні після їі спалаху в 2013-2014 pp.
} 
реальну цінність успіхів Польщі та $\mathrm{CC}^{18}$. Процеси, що відкрилися під час Української кризи і в посткризовий період дозволили Польщі використати українські больові точки, які оголилися, тим самим формуючи умови до поглиблення реформування України.

Європейський Союз часто критикують за відсутність необхідної реакції на Євромайдан/Революцію Гідності, як на знакові події, що несли кардинальні зміни для регіону. Справді, позиції дослідників щодо участі ЄС у подоланні кризи в Україні диференціюються між критикою $С С$ за його «повільну і реактивну реакцію» ${ }^{19}$, яку він показав на початку 2014 р., що послабило імідж $Є С$, як «представника цінностей», за які виступав Свромайдан ${ }^{20}$, до упевненості, що ЄС діяв як «велика сила» під час кризи безпеки в Україні ${ }^{21}$.

У свою чергу, більшість дослідників вважає, що Польща, у контексті Вільнюського саміту Східного партнерства, під час протестів «Свромайдану» та збройного конфлікту в Україні, «практично використала майже весь свій дипломатичний та політичний капітал у позицію $\mathrm{CC}$ щодо України»22. Після початку протестів на Майдані в листопаді 2013 р. офіційна Варшава відіграла провідну роль у процесі посередництва, заснованому на ії досвіді під час Помаранчевої революції 23 . Польські політики 3 усіх політичних таборів були активні під час протестів, підтримуючи Україну. Тогочасний міністр закордонних справ Польщі Р. Сікорський висловився за пом'якшення бюрократичних процедур СС, лідер консервативної опозиції Я. Качинський підтвердив перспективи України щодо членства в $\mathrm{CC}^{24}$, а Д. Туск проводив успішну «човникову дипломатію», яка охоплювала всіх ключових партнерів з $\mathrm{CC}^{25}$. Отже, у контексті розвитку кризи в Україні, представники польської політичної еліти, польські президенти, прем'єрміністри та міністри закордонних справ взяли (більш-менш) активну позицію щодо України, відвідували з офіційними візитами Україну та проводили тематичні ініціативи, як на двосторонньому рівні, так і на рівні $\epsilon^{26}$.

Вмотивованість впливу Польщі на України в умовах Української кризи вимагає від нас з'ясувати чи Польща прагнула проводити політику на посилення демократичних аспірацій чи на подолання кризи без вагомих внутрішньополітичних інвестицій. Внутрішньополітичні особливості Польщі упродовж зазначеного періоду вплинули на ідеологічну політику Польщі щодо України. Симптоматично, що під час гострої фази Української кризи, Польща не могла сформувати консолідовану загальнонаціональну позицію у питанні підходів щодо політичного й ідеологічного впливу на Україну, оскільки в самій Польщі точилася внутрішньополітична боротьба за визначення майбутнього вектору розвитку країни. Щоправда, у питанні засудження російського втручання та надання підтримки новій українській владі між урядовою коаліцією та опозицією, існував консенсус, який був зафіксований Польським Сеймом, у резолюції від 5 березня 2014 p. ${ }^{27}$.

Загострення Української кризи прийшлося на президенство Б. Комаровського (2010-2015 pp.) i А. Дуди (2015-2020 рр.). Цей період слід розділити на період Євромайдану і українськоросійську гібридну війну. Польща усвідомлювала, що у неї замало можливостей для самостійного реагуванняя ${ }^{28}$. Така позиція Польщі не мала прямого відношення до поширення демократії, а лише опосередковано створювала умови для подальшої трансформації України в напрямку європейських стандартів вже як суспільства, яке пройшло через внутрішній конфлікт, у перспективі інтегроване і готове до демократичної консолідації і перетворень. Погодимося із польським дослідником Р. Зіємбою, що упродовж Української кризи 2014 р. офіційна Варшава зосе-

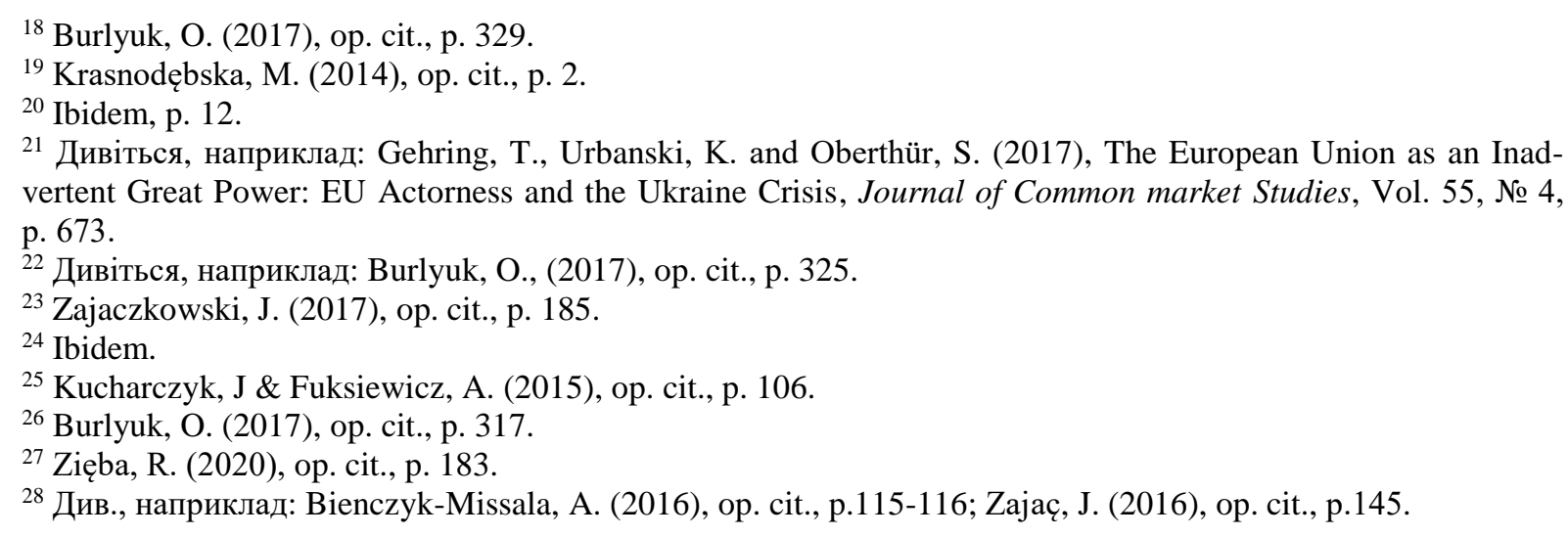


редилася на «допомозі новій українській владі в Києві, критиці російського втручання, заклику ввести санкції проти Росії, військовій підтримці НАТО для України та посиленні східного флангу Альянсу» ${ }^{29}$. Однак, Польщу цілком можна й звинуватити у неспроможності подолання Української кризи, тим самим загострюючи внутрішньополітичний порядок денний. Так, Польща свідомо відмовилася від ролі посередника в Українській кризі, а дії Польщі не мали пом'якшувального ефекту на кризу ${ }^{30}$.

Українська криза актуалізувала питання майбутнього розвитку українського політичного режиму, збереження тих демократичних, читай європейських, надбань, які були зроблені під час Євромайдану і Революції Гідності, потребували термінового посилення його ідеологічної складової. Питання демократичної консолідації в Україні по факту цієї електоральної революції було важливим для Польщі у контексті авторитарної відповіді з боку РФ, яка обернулася територіальними і громадянськими втратами для України. Потреба порятунку української демократії була підтримана майже всіма польськими політичними колами, які вимагали «європейського рішення» для України ${ }^{31}$. Отже, Польщі довелося включитися в боротьбу із просуванням російського авторитаризму в умовах українсько-російської гібридної війни.

Отже, Польща була залучена в подолання Української кризи 2013-2014 pp. на рівні, який був дозволений більш потужними європейськими державами, які перебрали на себе левову частку цієї місії, виводячи Україну на новий рівень геополітичного змагання. Фіксація перемоги в електоральній революції підштовхували українське суспільство до необхідності переходу на нові демократичні стандарти, які були пов'язані із широкими реформами: реформи місцевого самоуправління, боротьбі із корупцією і реформам у тих чи інших секторах. Головним досягненням Української кризи $є$ те, що українсько-польські відносини отримали новий поштовх і бачення під кінець 2013 р., що говорить про те, що дві сторони узгоджували свої позиції в умовах формування нової геополітичної ситуації.

Участь третіх країн у питанні поширення демократії щодо України в умовах кризи підводить до ролі Російської Федерації і США, які, поруч з іншими державами, зокрема й Польщею, впливали на розвиток внутрішньої ситуації в України, а саме: поширення демократії як відповідь на просування російського авторитаризму, або, навпаки. Питання першопричини як провокації і справедливої відповіді у розвитку подій на пострадянському просторі у контексті глобальних процесів не носить принципового значення. Поширення демократії у даному випадку тісно пов'язане із європейськими прагненнями України, натомість просування російського авторитаризму пов'язане із ревізією наслідків розпаду СРСР і формуванням концепції Великої Євразії. Європейський Союз у своїй боротьбі за власне розширення використовував механізми просування ідеологічних цінностей, зокрема демократії, натомість Російська Федерація, визначившись головним його антагоністом 3 кінця 1990-х рp. - початку 2000-х рр., поширювала власні ідеологічні ресурси: «русскій мір», суверенний авторитаризм і суверенну демократію ${ }^{32}$. Однак, розвиток Української кризи довів, що, Росія легко схиляється до використання жорсткої сили у випадку неефективності на фронті ідеологічної боротьби.

Демократизація українського політичного режиму не належала до пріоритетів СС і США. До такої думки приходить С. Коен, який цитує «СС вимагав - безвідповідально і в ультимативній формі», щоб «демократично обраний президент глибоко розділеної країни вибирав між Свропою та Росією» ${ }^{33}$. Натомість, деякі американські дослідники вважають, що «США спровокували кризу в Україні», або що «США несуть відповідальність за неї разом зі своїми європейськими союзниками» ${ }^{34}$. «СC не хотів підтримувати демократичні зміни в Україні, але хотів, щоб країна мала проєвропейську зовнішньополітичну орієнтацію, щоб створити противагу Росії» ${ }^{35}$.

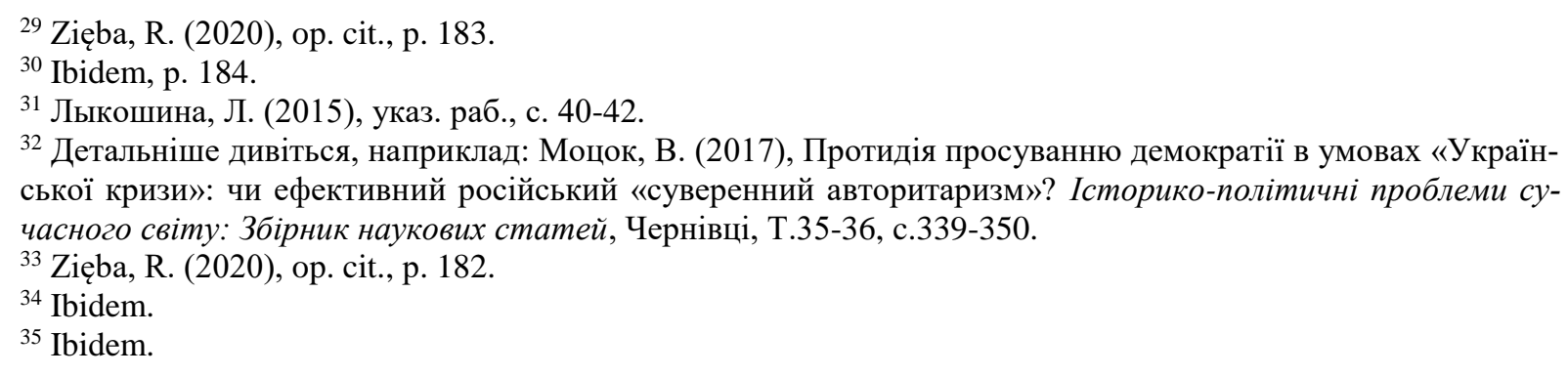


По-друге, залишається питання про сприяння Польщі у боротьбі із поширенням російського авторитаризму в контексті українсько-російської гібридної війни 2014-2020 pp., а саме: чи воно було спрямоване на утримання демократичних надбань Україною чи внутрішньополітичну стабілізацію задля подолання кризи. Ми виходимо з припущення, що російська авторитарна відповідь посилила процеси демократичної консолідації України. Зі свого боку Польща була спроможна сприяти пом'якшенню або посиленню українсько-російського конфлікту, тим самим формуючи умови для глибинної трансформації України в один чи інший бік.

Російська авторитарна відповідь на демократичний поступ України на межі 2013-2014 pp. була логічним продовженням ланцюжка дій ідеологічного характеру з боку колективного Заходу, який переріс у формат військового протистояння, що, у свою чергу, свідчить про недостатні політико-ідеологічні ресурси Росії у боротьбі за східноєвропейський простір. Активне втручання Російської Федерації в українські справи могло як посилити поширення демократії і, в цілому, реформування України у напрямку європейської інтеграції, так і пригальмувати демократизацію України. Еволюція Української кризи доводить, що російське втручання у вигляді елементів поширення авторитаризму і гібридної війни на українській території, посилювало процеси демократичної трансформації України, оскільки спонукало українське керівництво до більш активних дій з реформування країни.

Російсько-українська гібридна війна змушувала колективний Захід здійснювати більш активні дії із підтримки України. Свропейський Союз зайняв більш принципову позицію щодо агресивних дій Росії лише після гібридного анексування Криму і катастрофи рейсу МН17 Малазійських авіаліній ${ }^{36}$. Міжнародна реакція Польщі на дії Росії під час окупації Криму, яка теж проходила за стандартами гібридної війни, цілком відповідала міжнародним нормам. 3 часу розвитку гібридного протистояння з Росією з весни 2014.p., Польща не брала участь у мирних переговорах із певних і вагомих причин на які ще прийдеться давати відповіді. Всі формати переговорів, а саме: Женевський, Нормандський і Мінський, не передбачали участі польської держави, що підтверджує, зокрема, й необхідність незаангажованої ролі Польщі у розвитку міжнародних відносин на східноєвропейському напрямку на перспективу. Польський дослідник А. Шептицький пов'язує це із слабкістю Польщі порівняно із іншими центрами сили та українськопольським «стратегічним партнерством» ${ }^{37}$.

У свою чергу, Польща підтримала $Є С$ в його протидії поширенню російського ідеологічного впливу під час українсько-російської гібридної війни, як наступного етапу української кризи. Поширення демократії щодо України тісно пов'язане із просуванням авторитаризму з боку РФ, тому будь-які спроби підсилити європейські прагнення України сприяють ії̈ демократизації. Дослідники, здебільшого, визначають авторитарну відповідь на хвилю демократизації, як найбільш логічну реакцію головного конкурента в межах ідеологічного протистояння. Росія, як головний ідеологічний і геополітичний конкурент Заходу на сході європейського континенту, доклала значних зусиль для розробки концепції суверенної політичної ідеології, яку можна експортувати. Такими концепціями у різний час пропонувалися «суверенна демократія» $\mathrm{i}$ «суверенний авторитаризм» ${ }^{38}$, однак, якщо підбити їх підсумок, то потенціал російського ідеологічного впливу на пострадянському просторі або не був ще у достатній мірі продемонстрований до цього часу, або має схильність переростати зі сфери «м'якої сили» у «жорстку», про що свідчить досвід російсько-української гібридної війни.

Симптоматично, що Польща, несучи основний геополітичний вантаж боротьби із Російською Федерацією з-поміж держав СС, не приймала участі у політичному врегулюванні кризи в Україні. На думку Р. Зіємби, «Польща, без сумніву, на вимогу Росії (за схваленням західних держав), була виключена з міжнародних дискусій, спрямованих на вирішення кризи в Україні» i не була включена до Нормандського формату, до складу якого входять Франція, Німеччина, Україна та Росія ${ }^{39}$. Погодимося із Р. Зіємбою, що політику Польщі щодо мирних домовленостей слід трактувати як «провал» ${ }^{40}$ польської дипломатії та «покарання» ${ }^{41}$, оскільки польські урядо-

\footnotetext{
${ }^{36}$ Krasnodębska, M. (2014), op. cit., p. 2.

${ }^{37}$ Szeptycki, A. (2016), op. cit., p. 75.

38 Детальніше дивіться, наприклад: Моцок, В. (2017), вказ. пр., р. 339-350.

${ }^{39}$ Zięba, R. (2020), op. cit., p.184.

${ }^{40}$ Ibidem.

${ }^{41}$ Ibidem.
} 
вці робили антиросійські заяви, що не дозволило Польщі брати участь у Норманському форматі. На думку колишнього прем'єр-міністра Польщі Л. Міллера, відсутність участі Польщі у зустрічі в Берліні 17 серпня 2014 р. було «великим ударом по нашому престижу», і що «подібні переговори повинні відбуватися у Варшаві, тому що ми єдина країна, яка межує з Росією та Україною» ${ }^{42}$. У контексті розвитку гібридної війни, Польща виступала із пропозицією альтернативного майданчику мирних переговорів, який, щоправда, був відхилений на користь Нормандського формату. Хоча, можна погодитися із А. Турковським, що на початку Української кризи Росія відігравала важливу роль у зовнішній політиці Польщі і остання зовсім не хотіла виглядати антиросійською чи «русофобською» в очах держав-членів $\mathrm{CC}^{43}$. У цілому, говорячи про період 1991-2020 pр., польсько-російські відносини характеризувалися як партнерські.

Упродовж тривалого часу, як мінімум з часу Помаранчевої революції, Польща сприймалася Москвою як «неформальний лідер» ${ }^{44}$ країн, які є недружніми до Росії і формувала політику із блокування ініціатив Заходу із поширення демократії. Білоруська революція 2020 р., яка має всі шанси перерости в ще одну кризову ситуацію в Східній Європі, теж активно лобіюється з боку Польщі. Зовнішньополітична присутність Росії в українській політиці в умовах загострення кризи внесла свої корективи у поведінку Польщі у тому числі. Всі польські уряди були спрямовані на підтримку України через сприяння демократії, підтримку «кольорових революцій»у пострадянських державах та підтримку прозахідного курсу в їх зовнішній політиці, включаючи їх амбіції вступити до НАТО та ЄС.

Проте, в умовах посилення Української кризи, Польща повинна була шукати своє місце в іiі розв'язанні чи, напроти, посиленні, і польсько-російські відносини могли б бути важливими у формуванні нового підходу. Ще до початку кризи відносини між Польщею і Росією були непростими. Польська ідентичність і дилема визначалася як «місце країни на карті між двома потужними державами: Німеччиною та Росією» ${ }^{45}$.

На думку польського дослідника Р. Зіємби, участь Польщі на боці України погіршила відносини між Польщею та Росією більше, ніж у будь-який час після розпаду СРСР, оскільки під час Української кризи Польща поводилася «істерично, припускаючи, що Росія не зупиниться на анексії Криму, а здійснить збройну агресію проти Польщі та країн Балтії» ${ }^{46}$. У травні і листопаді 2014 р. очільники польського МЗС сприймали Росію як головну загрозу польській та міжнародній безпеці. Подібні заяви з'явилися і в Національній безпеці Стратегія Республіки Польща від 5 листопада 2014 р. Така критична і непохитна позиція Польщі щодо Росії не сприяла ані вирішенню кризи, ані нормалізації відносин з Москвою ${ }^{47}$.

Отже, станом на кінець 2020 р. можна припустити, що зусилля ЄС і Польщі були спрямовані на стримування російського авторитаризму, використовуючи певний набір зовнішньополітичних інструментів, яких виявилося достатньо, а саме: політичні інструменти й економічні санкції. У цілому, наступний етап Української кризи, який ми асоціюємо із російсько-українською гібридною війною, формує достатньо підстав для посилення українсько-польських відносин, зокрема й щодо підтримки Польщею консолідації демократичного режиму в Україні, як найбільш дієвого і логічного інструменту в цій ідеологічній боротьбі за Східну Свропу. Гіпотетично, боротьба на ідеологічному рівні перешкоджає іiі переростанню в гарячу фазу до певного етапу, оскільки зосереджує й економить ресурси обидвох сторін у площині «м'якої сили».

Висновки. Польща долучилася до просування демократії Європейським Союзом щодо України в умовах Української кризи і посткризовий період, беручи до уваги як власні національні інтереси, які не в кожному випадку співпадали із інтересами $\mathrm{CC}$, так і інтегровану позицію $\mathrm{CC}$ щодо пришвидшення демократичної трансформації України. Прискорене подолання Української кризи без відчутних результатів демократичної консолідації українського політичного режиму не співпадало з інтересами колективного Заходу, тому наступний етап Української кризи у вигляді українсько-російської гібридної війни перейшов у розряд низької інтенсивності. Кризові процеси у внутрішній політиці України є необхідним і дієвим інструментом для демокра-

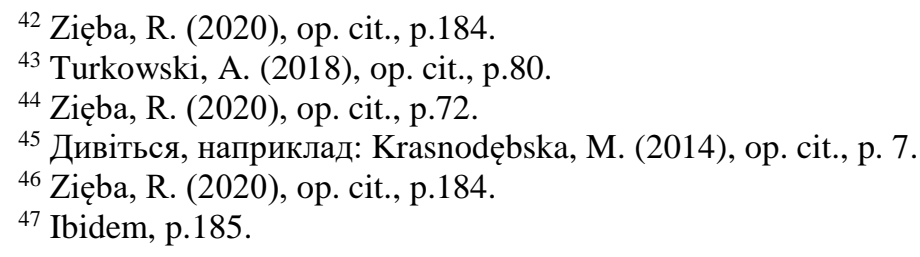


тичної трансформації суспільства. Ми приходимо до висновку, що зусилля Польщі як у межах $\mathrm{EC}$, так і одноосібно, передусім, були спрямовані на посилення трансформаційних процесів в Україні, які зосереджувалися навколо й практичної реалізації концепції поширення демократії в обраних сферах. Натомість, подолання кризи із збереженням вихідних установок не збігалося 3 інтересами як Польщі, так і СС

У сформульованій проблемі вже $є$ натяк на відповідь на поставлене питання: Польща долучилася до зусиль $\mathrm{CC}$ із чергового етапу поширення демократії щодо України, який перейшов у кризову стадію, тим самим всі наступні зусилля були спрямовані на ефективне використання кризового періоду задля посилення трансформаційних процесів. Отже, Польща брала активну участь як у просуванні демократії щодо України, так і в подоланні кризи на перспективу, використовуючи власні політичні і ідеологічні ресурси. Ми підтверджуємо запропоновану гіпотезу, що поширення демократії є більш тривалим і фундаментальним процесом, який потребує залучення різного роду мотивуючих тригерів, які можуть зіграти епізодичну, однак вагому, роль на тому чи іншому етапі. Таким чином, Українську кризу і українсько-російську гібридну війну ми розглядаємо як вагомий мотивуючий фактор, який здійснює важливу роль у посиленні демократичних орієнтацій українського суспільства, а участь зовнішніх сил, передусім, консолідованого Заходу, як істотний чинник цього процесу.

\section{Список джерел}

1. Лыкошина, Л. (2015), Российско-польские отношения в 2004-2014 гг.: От Майдана до Майдана, Страны Восточной Европы и Россия: развитие отношений в 2005-2015 г2.: сб. науч. тр. Отв. ред. Игрицкий И.Ю., ИНИОН РАН, Москва, с. 29-46.

2. Моцок, В. (2017), Протидія просуванню демократії в умовах «Української кризи»: чи ефективний російський «суверенний авторитаризм»? Історико-політичні проблеми сучасного світу: Збірник наукових статей, Чернівці, Т. 35-36, с. 339-350.

3. Bienczyk-Missala, A. (2016), Poland's Foreign And Security Policy: Main Directions, Revista UNISCI / UNISCI Journal, № 40, p. 101-118.

4. Burlyuk, O. (2017), Same End, Different Means: The Evolution of Poland's Support for Ukraine at the European Level, East European Politics and Societies and Cultures, Vol. 31, № 2, p. 311-333.

5. Gehring, T., Urbanski, K. and Oberthür, S. (2017), The European Union as an Inadvertent Great Power: EU Actorness and the Ukraine Crisis, Journal of Common market Studies, Vol. 55, № 4, p. $727-743$.

6. Krasnodębska, M. (2014), Europeanization of Poland's Strategic Culture: Managing the 2013/14 Ukraine Crisis Paper Proposal. Available at: https://ecpr.eu/Filestore/paperproposal/ 48346673-2aa6-4313-9eb1-1e05bb00d5ec.pdf [Viewed 1 December 2020].

7. Krasnodeb̨ska, M. (2020), Managing the Ukraine Crisis: A Triumph of Poland's EU Politics? Politics of Stigmatization. Poland as a 'Latecomer' in the European Union. Palgrave Studies in International Relations, p. 187-225.

8. Kucharczyk, J \& Fuksiewicz, A (2015), The Long Shadow of the Kremlin: Polish Domestic Reactions to the Russian-Ukrainian Conflict, Kucharczyk, J \& Mesežnikov, G (eds), Diverging Voices, Converging Policies: The Visegrad States' Reactions to the Russia-Ukraine Conflict, HeinrichBöll-Foundation, p. 102-114.

9. Pospieszna, P. \& Galus, A. (2018), Promoting active youth: evidence from Polish NGO's civic education programme in Eastern Europe, Journal of International Relations and Development, Vol. 23, № 1, p. 210-236.

10. Sierakowski, S. (2020), Belarus Uprising: The Making of a Revolution, Journal of Democracy, Vol. 31, № 4, p. 5-16.

11. Szeptycki, A. (2016), Poland-Ukraine Relations, Revista UNISCI / UNISCI Journal, № 40, p. 57-76.

12. Turkowski, A (2018), Polish Intelligentsia Totems in Elites' Struggles for Legitimization: The Case of Jerzy Giedroyc and Poland's Eastern Policy, East European Politics and Societies and Cultures, Vol. 33, № 1, p. 66-88.

13. Zajaç, J. (2016), Poland's Security Policy The West, Russia, and the Changing International Order. Palgrave Macmillan. 
14. Zajaczkowski, J. (2017), Trading Solidarity For Security? Poland And The Russian-Ukrainian Crisis, Идеология и политика, №1(17), p. 168-234.

15. Zięba, R. (2020), Poland's Foreign and Security Policy Problems of Compatibility with the Changing International Order. Palgrave Macmillan.

\section{References}

1. Lykoshina, L. (2015), Rossyjsko-polskie otnoshenia v 2004-2014 gg.: Ot Maidana do Maidana, Strany Vostochnoj Evropy i Rossiya: razvitie otnosheniy v 2005-2015 gg.: sb. nauch. tr. Otv. red. Igritskiy I.Yu. INION RAN, Moskva, s. 29-46.

2. Motsok, V. (2017), Protidiya prosuvannyu demokrati v umovah "Ukrainskoi kryzy": chi efektivnyy rossiyskiy "suverennyy avtoritaryzm"? Istoriko-politichni problemy suchasnogo svitu: Zbirnik naukovyh statey, Chernivtsi, T.35-36, s. 339-350.

3. Bienczyk-Missala, A. (2016), Poland's Foreign And Security Policy: Main Directions, Revista UNISCI / UNISCI Journal, № 40, p. 101-118.

4. Burlyuk, O. (2017), Same End, Different Means: The Evolution of Poland's Support for Ukraine at the European Level, East European Politics and Societies and Cultures, Vol. 31, № 2, p. 311-333.

5. Gehring, T., Urbanski, K. and Oberthür, S. (2017), The European Union as an Inadvertent Great Power: EU Actorness and the Ukraine Crisis, Journal of Common market Studies, Vol. 55, № 4, p. 727-743.

6. Krasnodębska, M. (2014), Europeanization of Poland's Strategic Culture: Managing the 2013/14 Ukraine Crisis Paper Proposal. Available at: https://ecpr.eu/Filestore/paperproposal/ 48346673-2aa6-4313-9eb1-1e05bb00d5ec.pdf [Viewed 1 December 2020].

7. Krasnodę̧ska, M. (2020), Managing the Ukraine Crisis: A Triumph of Poland's EU Politics? Politics of Stigmatization. Poland as a 'Latecomer' in the European Union. Palgrave Studies in International Relations, p. 187-225.

8. Kucharczyk, J \& Fuksiewicz, A (2015), The Long Shadow of the Kremlin: Polish Domestic Reactions to the Russian-Ukrainian Conflict, Kucharczyk, J \& Mesežnikov, G (eds), Diverging Voices, Converging Policies: The Visegrad States' Reactions to the Russia-Ukraine Conflict, HeinrichBöll-Foundation, p. 102-114.

9. Pospieszna, P. \& Galus, A. (2018), Promoting active youth: evidence from Polish NGO's civic education programme in Eastern Europe, Journal of International Relations and Development, Vol. 23, № 1, p. 210-236.

10. Sierakowski, S. (2020), Belarus Uprising: The Making of a Revolution, Journal of Democracy, Vol. 31, № 4, p. 5-16. 57-76.

11. Szeptycki, A. (2016), Poland-Ukraine Relations, Revista UNISCI / UNISCI Journal, № 40, p.

12. Turkowski, A (2018), Polish Intelligentsia Totems in Elites' Struggles for Legitimization: The Case of Jerzy Giedroyc and Poland's Eastern Policy, East European Politics and Societies and Cultures, Vol. 33, № 1, p. 66-88.

13. Zajaç, J. (2016), Poland's Security Policy The West, Russia, and the Changing International Order. Palgrave Macmillan.

14. Zajaczkowski, J. (2017), Trading Solidarity For Security? Poland And The Russian-Ukrainian Crisis, Ideologija i politika, №1(17), p. 168-234.

15. Zięba, R. (2020), Poland's Foreign and Security Policy Problems of Compatibility with the Changing International Order. Palgrave Macmillan. 